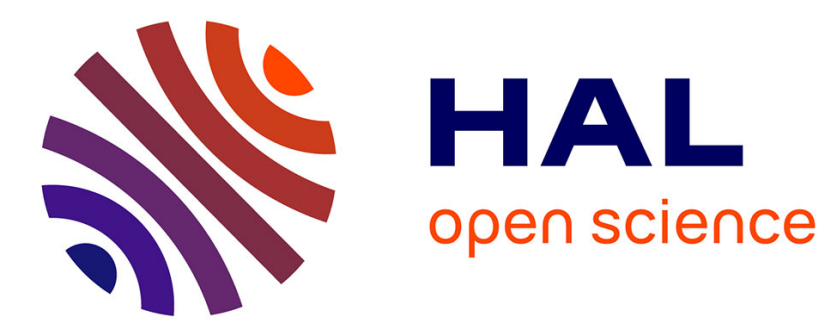

\title{
A theological approach to organizational visual representations
}

\author{
Aziza Laguecir, Bernard Leca
}

\section{To cite this version:}

Aziza Laguecir, Bernard Leca. A theological approach to organizational visual representations. 2017. hal-01510654

\section{HAL Id: hal-01510654 \\ https://essec.hal.science/hal-01510654}

Preprint submitted on 19 Apr 2017

HAL is a multi-disciplinary open access archive for the deposit and dissemination of scientific research documents, whether they are published or not. The documents may come from teaching and research institutions in France or abroad, or from public or private research centers.
L'archive ouverte pluridisciplinaire HAL, est destinée au dépôt et à la diffusion de documents scientifiques de niveau recherche, publiés ou non, émanant des établissements d'enseignement et de recherche français ou étrangers, des laboratoires publics ou privés. 


\title{
E \\ ESS EC \\ BUSINESS SCHOOL
}

\section{A THEOLOGICAL APPROACH TO ORGANIZATIONAL VISUAL REPRESENTATIONS}

\author{
RESEARCH CENTER \\ AZIZA LAGUECIR, BERNARD LECA \\ ESSEC WORKING PAPER 1704
}

FEBRUARY 2017 


\title{
A THEOLOGICAL APPROACH TO ORGANIZATIONAL VISUAL REPRESENTATIONS
}

\author{
Aziza Laguecir \\ Accounting Department \\ Kedge Business School \\ 680 cours de la Libération \\ 33405 Talence \\ FRANCE \\ e-mail : aziza.laguecir@gmail.com \\ Bernard Leca \\ ESSEC Business School \\ 3, avenue Bernard Hirsch \\ CS 50105 \\ 95021 Cergy-Pontoise Cedex \\ FRANCE \\ Fax : + 33(0)134439277 \\ Tel: + 33(0)134439722 \\ e-mail : bernard.leca@essec.edu
}




\title{
A THEOLOGICAL APPROACH TO ORGANIZATIONAL VISUAL REPRESENTATIONS
}

\begin{abstract}
We argue that analytical and critical aspects of theology can contribute to organizational research, and potentially assist in elaborating new concepts. To lay this out, we use Christian orthodox theology of icons as an analytical framework to study organizational visual representations. We generate three important insights. First, we point to the need, so far neglected, to question and theorize the relation between the representation and what is represented. Second, we highlight the prominence of symbolism over aesthetic aspects. Third, we underline that images are both embedded within meaningful relationships with other images, and used in social and power relationships. Building on these insights, we elaborate the notion of epistemic power to account for the capacity of visual representations to provide knowledge of an object of inquiry which cannot be immediately conscripted nor clearly perceived in its entirety. We contribute to the integration of theological analysis in organizational research by showing how it can further extend our understanding of secular organizational settings.
\end{abstract}

Keywords: Epistemic Power, Religion, Theological approach, Organizational Visual Representations

\section{INTRODUCTION}

The role of religion and spirituality in contemporary societies and organizations has received increasing interest in organizational studies (e.g. Chan-Serafin, et al. 2013; Creed, et al. 2010; Dyck 2014; Khan and Koshul 2011; Tracey 2012). However, scholars have paid limited attention to theological analysis. When mentioned, theology is mostly referenced to expose religious beliefs and doctrines (e.g. Creed, et al. 2010; King and Haveman 2008; Parker 2009). More recently, Sørensen, et al. (2012) initiated a "theological approach of organizations", suggesting the use of theology to reveal religious dimensions of apparently secularized organizations. While those works focus on theology, they consider it an ensemble of beliefs and notions rather than an analytical discipline on its own with proper reasoning and debates. In this paper, we suggest extending this focus by referring to theology as an analytical tradition involving skepticism, critical thinking and reflexivity. Indeed, theology, as the critical study of the divine nature (Augustine of Hippo 2004:426), is a form of critical thinking that attempts to build a logical discourse (Logos) on God (Theos) by rigorous and critical analysis (Congregation for the Doctrine of the Faith 1990). Therefore, theology conciliates skepticism and spirituality. Nevertheless, to the best of our knowledge, this analytical aspect has not been considered in organizational research. 
The purpose of this paper is, therefore, to mobilize this neglected aspect of theology and show how it can contribute to theorizing organizational situations, including those that are secular, and potentially assist in elaborating new concepts. We argue that insights can be drawn from theological debates and analysis to further expand our understanding of organizational processes and practices, organizing and managing.

We draw from theological debates and analysis to further theorize a specific organizational phenomenon, i.e., organizational visual representations. There are two motives for such a study. First, while visual representations are a growing domain of research (Meyer, et al. 2013), authors lament that studies are overwhelmingly empirically driven and call for further theorization (Bell and Davison 2013). Second, there is a long theological tradition of debating and analyzing visual representations, particularly in Christian orthodox theology, of religious images (i.e., icons) and includes a major crisis that eventually led to the development of a theology of icons (Ouspensky 1992).

We argue that drawing from Christian orthodox theology assists in advancing the theorization of visual representations in management in three ways. First, the Christian orthodox theology evinces the epistemic dimension of visual representations. This indicates the need, which has previously been neglected, to question and theorize the relationship between the representation and what is represented and consider how actors in organizations understand this relationship. Second, Christian orthodox theology emphasizes the importance of icons' symbolism, considering this aspect more important than the aesthetic aspect. The icons' symbolism also reveals the importance of the actors' visual literacy to apprehend those symbols. Finally, the debates and analysis of Christian orthodox theology indicate the relational aspect of images as they are both embedded within meaningful relationships with other images and used in social and power relationships. Building on those insights, we elaborate the notion of epistemic power to explain the capacity of visual representations to provide knowledge of an object of inquiry, which cannot be immediately conscripted nor clearly perceived in its entirety.

We, therefore, show how theology can be used to contribute to theorization in organizational research. More broadly, this article contributes to the efforts to use theology to advance our understanding of organizations (Sørensen, et al. 2012). We share this interest for theological notions while extending it by focusing on the analytical and theoretical potential of theology to analyze symbols and question storytelling within organizations. Our work also enriches 
recent research on organizational visual representations (Bell and Davison 2013; Meyer, et al. 2013) as we use theology to develop theoretical insights revealing the characteristics of visual representations and, more specifically, their epistemic power.

We structure the paper as follows. First, we review the current integration of theology in organizational research and discuss how this can be extended using theology's analytical and critical dimensions. Second, we present the insights that can be drawn from Christian orthodox theology for research on organizational visual representations. We conclude with a discussion of the broader contributions of this research and suggest directions for future research.

\section{DRAWING FROM THEOLOGY TO ANALYZE VISUAL REPRESENTATIONS IN ORGANIZATIONS}

Recently, researchers have increasingly suggested the need to focus attention on the role of religion and spirituality in organizational life (Sørensen, et al. 2012; Tracey, et al. 2014). These dimensions have been identified as playing key roles in organizational decision making (Koerber and Neck 2006) or individual behavior (Bell and Davison 2013). Research has consequently engaged with the sociology of religions to develop a comprehensive understanding of religion within organizations (Tracey 2012; Tracey, et al. 2014).

Building on this increasing interest, some researchers have begun exploring beyond individuals' beliefs, spirituality and religion as sophisticated intellectual constructions that can provide important insights into organizational life. For instance, Parker (2009) used the writings of Pseudo-Dionysius on the hierarchy of angels to draw parallels and reflect on the notion of organizational hierarchy. Sørensen, et al. (2012) drew the contours of a more systematic "theology of organizations". This approach suggests that the way actors think about and act in organizations is profoundly structured by theological concepts, often subconsciously. Sørensen, et al. (2012:67) suggest the following:

“(...) (1) analyze organizational concepts as secularized theological concepts, (2) show how theological concepts have survived unaltered in organizational contexts and (3) show how theological concepts have been corrupted or lost their original meaning when deployed in organizational contexts." 
Our intention in this paper is to further expand the connection between religion and organizational research by taking a new approach. We intend to consider theology not only through its concepts but also through its reasoning and explore how this analytical framework can contribute to research in organizational studies. In this paper, we use theology as a tradition of critical debates and analysis. From this view, theology is construed as a rational discussion of assertions regarding their consistency with the divine message. It is critical to debate and distinguish between different contradictory interpretations and determine which is relevant. In the following sections, we illustrate how using spirituality-based reasoning can enrich our analysis of secular organizational phenomena such as organizational visual representations.

Visual management studies is a burgeoning (Meyer, et al. 2013), but arguably, undertheorized domain. In reviewing the related literature, Bell and Davison (2013) insist that this domain is currently overwhelmingly empirically driven, with researchers focusing on methods, and call for the development of theoretical approaches. To contribute, we draw from theology and, more specifically, from the Christian orthodox tradition and its long practice of debates and analysis of religious images (i.e., icons). In particular, these debates have led to a 120 -year long crisis on the nature of images, known as the iconoclast controversy (Besançon 1994; Ivanovic 2012; Martin 2014; Mondzain 1996). The outcome of this crisis changed the way images were considered in the Byzantine Empire (Elsner 2012), and the Christian orthodox theology eventually developed a specific theology of icons (Ouspensky 1992). In the following section, we use this tradition as the basis to develop insights into visual representations for organizational research.

\section{VISUAL REPRESENTATIONS AS REPRESENTATIONS}

The first dimension of interest for organizational research in the Christian orthodox tradition is how it entirely redefined how images were considered in the Christian world through the iconoclast controversy. This controversy shifted the discourse on visual representation from an ontological to an epistemological level of analysis. Rather than focusing on the images themselves ${ }^{1}$, the entire controversy addressed what can be known through the image and revealed three types of attitudes of actors towards images. We first introduce those aspects and then discuss how they can contribute to visual management studies. 


\section{From the ontology of images to the epistemology of knowing what is represented}

The iconoclast (Greek for those who destroy images) controversy started with the decision of Emperor Leo III (717-741) to enforce the Mosaic banning of God's images in his Empire, where such images were becoming the focus of worship (see Appendix 1). In 726, Leo openly declared himself against the cult of images (Ivanovic 2012; Martin 2014). Tradition suggests that he symbolically had the ancient figure of the Christ that adorned the main entrance of the Imperial Palace removed and thus initiated an iconoclast policy. Leo III not only removed an image but questioned "the entire discourse on figurative images as means of enunciating or representing the holy" (Elsner 2012:378).

This new iconoclastic policy was not welcomed by the population and the majority of the ecclesiastic authorities (Ivanovic 2012). Leo III had to replace the Patriarch to make the Church follow the Imperial orders and officially establish an iconoclast policy (Ivanovic 2012). Supporters of icons, referred to as "iconophilous" (Greek for those who enjoyed images), fiercely opposed this policy (Martin 2014). The most prominent of them was John of Damascus, a monk based in Palestine who lived under the Caliphate (outside the Byzantine Empire) and, therefore, enjoyed a particular freedom of speech. The controversy lasted until 787, when the iconophilous Empress Irene called a new council (Ivanovic 2012; Martin 2014). Known as Nicaea II, this council settled an iconophilous position, largely embracing the views of John of Damascus, and ordered the destruction of all iconoclastic writings. Theological discussions on the role of icons continued until the Council of 843, but a consensus emerged on the relevance of honoring icons.

What emerged from this controversy is a theorization of images unprecedented in the GrecoRoman or Mosaic traditions (Alloa 2013; Elsner 2012). As Elsner (2012, p.385) emphasized, the iconoclastic controversy liberated "the image from an unarticulated and generally assumed ontological tie to its referent to place the image instead in an epistemological relationship to its referent". Before the controversy, images were considered, by nature, as either being able to accurately represent God or not. With this controversy, the theorization of images shifted from an ontological level (i.e., the image being or not being the entity represented) to an epistemological level (i.e., the image as a way to know about what is represented) (Elsner 2012). Both iconoclasts and iconophilous agreed that images cannot by nature accurately represent God. Where they disagreed was whether something trustworthy could be learned about God by contemplating the image. Iconoclasts argued that images were 
necessarily misleading because the only accurate representation of God was the communion. Iconophilous argued that images could provide some knowledge, even incomplete, about God.

From this view, visual representations are considered "re-presentations" (Mondzain 1996) and cannot, by essence, accurately and entirely account for what they present. What is important is not the image itself, but its relationship with what is represented. The power of the icon is based on this relationship with the underlying entity it represents. It operates as a transfiguration. Jesus is not in the icon, but the icon tends towards Jesus while also emphasizing its absence. This paradigm shift in the analysis of images from ontology to epistemology during the iconoclast controversy also led to the distinction between three different attitudes towards visual representations and their relationship to what is represented. We detail those attitudes in the next section.

\section{Three attitudes towards visual representations}

Based on the theological debates concerning the iconoclast controversy, three attitudes towards visual representations can be distinguished (cf. Table 1).

\section{TABLE 1 AROUND HERE}

First are the idolaters (also known as iconolaters), those who do not make a distinction between the representation and what is represented. They consider images consubstantial to the represented reality and as true and trustworthy. This position is rejected both by iconoclasts and iconophilous who consider that idolaters mistake the image for the reality. While condemned by both sides of the controversy as heathens' practices, such practices remained vivid in popular culture (Pentcheva 2010).

Second are the iconoclasts who rejected icons ${ }^{2}$ and opposed idolaters for their inability to distinguish between the image and the entity. Iconoclasts made a radical distinction between the image and the entity meant to be depicted. In their view, the image cannot offer an accurate representation. An icon is simply a piece of wood with colors on it, and nothing valuable can be known about God through adoring it. An image of Jesus was considered blasphemous notably because it meant to paint an image of the Godhead, which cannot be 
depicted. They consider it was at best misleading to try to represent what could not (and should not) be represented.

The third attitude is the iconophilous, which eventually became dominant. Like iconoclasts, iconophilous reject idolatry as in the Mosaic tradition. Nonetheless, while they argue that images must not be worshipped, they suggest that something can be learned from God through the image. The image could not be an accurate representation, but a means to access what is depicted. Consequently, iconophilous rejected both those who called the sacred images idols and those who resorted to them as to gods. John of Damascus indicates the following:

$$
\begin{aligned}
& \text { "An image is a likeness of the original with a certain difference, for } \\
& \text { it is not an exact reproduction of the original. [...] I do not worship } \\
& \text { matter; I worship the God of matter who became matter for my } \\
& \text { sake, and deigned to inhabit matter, who worked out my salvation } \\
& \text { through matter. I will not cease from honouring that matter which } \\
& \text { works my salvation!" (Damascus 730:1.16; 12.14). }
\end{aligned}
$$

The distinction made between worshipping (latreia) and honoring (proskynesis) is central. It indicates the rejection of idolatry because the nature of veneration is different. Honoring is a lower form of veneration compared to worship, which is only in relationship to God. John of Damascus argues that he does not reject the Mosaic tradition of banning of images of God, he rather further elaborates on it, making a distinction between the image and what is represented (Mondzain 1996). Damascus argued that icons can have value to the extent that they help believers to approach what is beyond the icon. The Second Council of Nicea (687) indicates that "the honour paid to an image traverses it, reaching the model, and he who venerates the image, venerates the person represented in that image." In summary, iconophilous are by essence incomplete representations of what is represented, yet can be useful to know about what is represented.

\section{Insights for organizational research}

We argue that two insights for organizational research can be drawn from the specific view of images and emerged during the iconoclast controversy.

First, the controversy insists on the importance of the epistemic dimension of visual representations, an aspect currently neglected by the empirically driven visual management 
studies. This current research tends to focus on those representations without questioning their relationship to the reality they are intended to depict. For instance, recent research on visual representations of corporate social responsibility (CSR) examines the rhetorical and framing effects of those representations in dedicated reports (Meyer, et al. 2013). However, they set aside the epistemic aspect - i.e., to what extent those visual representations can help or not to know about what is supposed to be represented, in the present case the reality of the CSR activities within the organizations. Empirically driven visual management studies might remain limited to a search for recurrences in those representations in isolation from organizational realities. Considering this epistemic aspect can help build more critical analysis regarding the relationships between visual representations and what they are supposed to represent, what we can learn through the representation and its necessary incompleteness. This potentially draws attention to the biases of those representations, their focus, and what they potentially hide.

Second, the different attitudes regarding icons reveal the importance of the viewer and that all actors do not engage in the same way with images. The three types of attitudes identified in the iconoclast controversy can then be used to illuminate how actors within organizations engage with visual representations.

Idolaters would correspond to those managers who consider visual representations an exact image of what is represented, and will not go beyond them to consider the reality of organizational practices. They tend to conflate the practices (represented) and the image (representation) of those practices. A spectacular example of idolatry is the case known as the "London Whale", which involves a \$2 bn trading loss at JP Morgan. The internal report issued after the case (JP Morgan Management Task Force 2013) shows that the trader activities were supervised through a representation (a model) that eventually was proven to be flawed ${ }^{3}$. While the trading team and the trader had repeatedly warned their hierarchy of the risk of an underestimation, the hierarchy instead relied on the representation and did not perform an audit to examine practices beyond this representation.

A second attitude, radically opposed to idolaters, is iconoclasts. Those actors are aware of the epistemic aspect of visual representations as supposedly providing knowledge on what is represented, but they do not trust the knowledge provided. They see representations as useless or misleading about what is supposedly represented. This iconoclast attitude would lead them to attempt to directly access what is beyond the representation without relying on the representation. This implies engagement in direct supervision when possible, for instance in 
small companies where executives can directly monitor the activities of their subordinates or in companies where managers have a limited span of control so that they can engage in closer supervision.

Finally, iconophilous are those who see representations as ways to learn valuable information about what is represented yet consider that such representations are necessarily incomplete. They then consider these representations as useful, yet partial and potentially biased, methods to learn about what is represented. As managers, they use visual representations but will complete them with direct supervision. An illustrative example can be found in the 2008 Societe Generale's trading loss by Jérôme Kerviel. In 2005, Alain Declerck was the supervisor of Jérôme Kerviel at Societe Generale Assets Management. A former trader with a practical knowledge of the job, Declerck used visual representations provided by the reporting tools and direct supervision to monitor the activities of the traders. In July 2005, drawing on his expertise and not only on the reporting tools, he discovered that Kerviel had maintained off-limits overnight positions for several days and had hidden them with fictitious transactions (p. 35 of the trial deliberations). Declerck was later replaced by Eric Cordelle as desk manager. Cordelle was a product structurer, with no previous knowledge of trading practices (as opposed to Declerck), who operated as an idolater. He relied on reporting tools and was not able to understand the many alerts he received from inside and outside because he lacked relevant knowledge to interpret them. He was eventually unable to either detect or prevent the fraud.

Focusing on the epistemological issue, the theological debates suggest taking a more reflexive position vis- $a$-vis visual representations. The three different actors' attitudes regarding icons are linked to an important aspect of icons, i.e., their codification and the symbolism of such icons, which make them difficult to understand.

\section{VISUAL REPRESENTATIONS AS CODIFIED SYMBOLIC IMAGES}

The codified aspects of religious icons are an important element of the Christian orthodox theology. A striking feature of icons is that they are neither naturalistic (they do not intend to reproduce nature), nor do they exhibit the painters' technical skillfulness. What matters in icons is not their aesthetic value, but how accurately they convey the divine message. Florensky vividly insists on the following (1996:82): 


\section{"The question is not whether an image is "skilfully" or "poorly" executed (such measures lie merely in the artist's intention); the question is, is she in reality the Mother of God?"}

Beauty is accepted as it serves the message, not when it deserves it. In Christian orthodox tradition, the icon is not referred to as a piece of art, but more often as the imprinting of an authentic image of spiritual existence and it has to conforms to it "in imagery, likeness, and essence" (Florensky 1996:91). For laypersons with no particular theological knowledge, Christian orthodox icons might all appear the same. This contrasts with other traditions, such as those of the Catholic Church, where artists enjoy much more freedom in painting holy characters and where aesthetics have a prominent place. Since the iconoclast controversy, Christian orthodox icons are clearly codified to avoid unorthodox misrepresentations that might mislead believers. The Council of Nicea II insisted that Christian orthodox icons were as important as theological discourse, granting to visual representations a place that is unique among monotheisms. Therefore, Christian orthodox icons must comply with specific features. When icons are considered by the Church to not convey the divine message, they are rejected. Icons are not meant to be naturalistic, they are symbolic. Archbishop Puhalo indicates the following: "all elements of a canonical icon are symbolic and contain a profound revelation; there is no naturalistic elements in this Liturgical art" (Archbishop Puhalo 2014:1). Consequently, icons follow very different aesthetical canons than Western religious art.

Ouspensky (1992) calls this approach "symbolical realism”, which includes symbolic approaches to perspective, light and the use of colors, among others. For instance, perspective is 'reverse' or 'inverted' (Ouspensky 1992). From a linear perspective, the painting provides a sense of depth and attracts the spectator's view into the painting; it has its own perspective. Conversely, in an inverse perspective, the representation is limited to the foreground with no vanishing point and the image is almost protuberant, thus entering the space of the viewer (Ouspensky 1992). Another characteristic is the lack of any specific source of light that can be identified in icons because it radiates from the figure.

Such symbolism makes it possible to vary the message conveyed, depending on the icon. Indeed, each icon conveys a very specific message. As examples, we detail the following two of the most distributed and used icons, both of which represent the Mother of God (Theotokos, literally 'God-Bearer') and the Child: the Hodegetria (She who shows the Way) (Figure 1) and the Eleousa (Tenderness Virgin) (Figure 2). In both paintings, Mary holds Jesus in her 
arms and there is a sense of communication and tenderness between the mother and the child. However, the meaning of those icons is very different.

\section{FIGURE 1 AROUND HERE}

\section{FIGURE 2 AROUND HERE}

The Hodegretria (Figure 1) is one of the most venerated icons, whose original was said by tradition to have been painted by St Luke himself (Ouspensky 1992; Ouspensky and Lossky 1999; Pentcheva 2006). This original was the most revered icon in Constantinople. In the Hodegretria, the Theotokos is always on the left. She holds the Child. Her chest and her left arm bear Him, hence the title of Sedes Sapientiae, seat of wisdom. While the Hodegretria uses her left arm to hold Jesus, her right hand points at Him. This gesture is meant to show "the way" towards truth and life. This symbolizes that the Virgin is the one who intercedes between humanity and God and she shows the way to God. It is also the face of the Virgin which shows the way. Her face often bends toward Jesus, and her eyes look at the viewer, while gazing into the distance as a reference to the future of the passion of Jesus. Mary offers the Child to the world for the salvation of humanity. The face of Jesus is not the face of child, despite his body having the proportions of child. He answers his mother's intercessory prayer by blessing with the right hand. The image expresses a notion of silent conversation through the hands of the Mother and the Child (Martin 2014; Ouspensky and Lossky 1999; Pentcheva 2006, 2010). In his left hand, he holds the scriptures.

While apparently similar, the Eleousa icon (Figure 2) is very different. This icon insists on the intimacy and affection between the Mother and the Child as they embrace each other. Again, according to the tradition, St Luke was the first painter of this type of icon. The faces are turned toward each other. This embrace between the Mother and the Child refers to infinite love, including Jesus' love for humanity. In particular, Jesus does not look at the viewer but at his Mother. There is not only tenderness in the eyes of Mary but also sadness. Her veiled eyes symbolize that she foresees Jesus' martyrdom. Jesus touches her face to comfort her, which is 
also interpreted as Him announcing the resurrection. He wraps at least one arm around her neck or shoulders. The Mother of God represents the Church, and this wrapping refers both to the love of God for man and the role of the Church in achieving this love.

While different, both icons have common features (Leloup 2000). In both, the Mother and the Child wear richly textured clothes. The Mother has her hair covered with a veil, which drops to her shoulders; it is never loose. The veil is usually red to refer to her suffering, with blue clothing under the veil referring to her humanity. The veil is marked with three starbursts. Depending on different traditions, these starbursts are either considered a reference to the Trinity or to virginity (before, during and after giving birth) of the Mother of God (Leloup 2000). Sometimes, the third star is covered by the Child who is part of the Trinity. Jesus himself is dressed in very rich clothes to refer to his status.

Because of such heavy symbolism, those messages are only accessible to believers with the relevant visual literacy. Only the viewer with relevant visual literacy can articulate the material and symbolic dimensions of icons. Icons are meant to orient the believer's vision and thoughts according to the specific part of the divine message the icon conveys. Icons are meant to work as translucent windows (Florensky 1996), allowing the believers to overcome the divide between the human and spiritual worlds. Those who lack the visual literacy only see the aesthetic image and will not be able to use it to access what is beneath.

We argue that these subtle nuances between two icons of the Virgin are of particular interest when it comes to analyze and theorize organizational visual representations. We do not intent to make an analogy between these two icons and organizational visual representations, but rather elaborate on the symbolism of such icons and how viewers literacy matter regarding such symbolism, in making sense of organizational visual representations. For this purpose, we use the example of strategic matrices.

\section{Insights for organizational research}

Drawing on the illustrative example of strategic matrices, we elaborate here how symbolism works for organizational visual representations, and how viewers make sense of them, mobilizing their literacy.

Symbols and codes are crucial to understand organizational visual representations such as strategic matrices. Corporate Portfolio Management (CPM) matrices are typically structured 
based on the following two dimensions: the attractiveness of the market and the competitive advantage of the company (with underlying assumptions that are rarely made explicit in the representation). Circles are often used to represent the different activities of the company and their relationships to each other. The size of the circle depends on the contribution of the activity to the turnover of the organization. The use of this common vocabulary of symbols and codes varies across matrices. While the CPM matrices might all appear the same to laypersons, experts (e.g., consultants, trained managers or academics) would distinguish them. Matrices consider different relationships, convey different messages and are not interchangeable. For instance, the BCG growth - share matrix insists on the relationship between market share and profit and better fits with consumers' products where such a relationship is relevant, rather than in industries where this relationship does not work and small market share can be highly profitable (Armstrong and Brodie 1994). The McKinsey/GE matrix addresses the same issue, but the assumed relationships are different, with broader definitions of the orthogonal dimensions (competitive strength and market attractiveness). These results are more complex to interpret because it is not assumed that there is a relationship between market share and benefits.

Only actors with the appropriate visual literacy can access these subtle differences. While the practical importance of management tools has been acknowledged (Whittington 2003), their visual aspect remains underexplored. Mobilizing icon analytical frames, we examine visual aspects of strategic matrixes as an illustrative example of organizational visual representations. This allows us to highlight important, yet little researched, aspects of organizational visual representations. The experts' ability to make such distinctions indicates the importance of visual literacy. Similar to icons, matrices have multiple underlying assumptions that are rarely made explicit. In the case of the BCG growth - share matrix, those assumptions include a focus on internal cash flow and ignorance of the capital market as a potential source of funding (Wensley 1981); a positive relationship between market share and cash generated (Henderson 1970); a product lifecycle that moves linearly from introduction to growth, maturity and decline; and the assumption that the activities in the portfolio are unrelated and independent from each other. Several studies have questioned those assumptions, indicating that they are not relevant in all contexts. Consequently, those works recommend using the BCG matrix carefully and certainly not in all cases (e.g. Day 1986; Haspeslagh 1982). A consequence is that the use of this matrix without considering the specific caveats to evaluate the situation leads to inferior strategic decisions (Armstrong and 
Brodie 1994). Only managers with the relevant knowledge of the underlying assumptions of such a matrix can evaluate if the matrix properly fits the situation, properly use it and accurately benefit from the analysis. Studies conclude that managers or students blindly following the matrix indicate idolater behaviors, where viewers and users lack the knowledge and associated reflexivity to see that matrices are visual representations orienting the vision in a specific way and are far from being universal.

Using the theology of icons as an analytical framework to examine organizational visual representations emphasizes the importance of the visual literacy of the organizational actors. The aesthetic dimension of them is considered secondary. At stake here is the ability of the representation to focus the viewer's attention on the primary concept (i.e., what is behind the visual representation).

\section{VISUAL REPRESENTATIONS AS RELATIONAL}

A third aspect emphasized by the Christian orthodox theology that can help advance visual management studies relates to the relational aspects of visual representations. In this section we examine the relationships among icons as established in iconostasis and how icons are used in liturgy to strengthen relationships within the community. We then discuss how these relational aspects can contribute to illuminate aspects of organizational visual representations.

\section{Relationships between images}

While icons are autonomous forms, they have links due to the religious figures they portray or episodes they reference. Those relationships are made explicit in iconostasis. Iconostasis, literally 'screen of icons', are large screens of icons that separate the sanctuary from the nave (particularly in Russian and Slavic churches) to prevent the worshippers from seeing what occurs near the altar (Figure 3).

FIGURE 3 AROUND HERE 
It has been theorized that iconostasis is not there to hide, but to help reveal. Pavel Florensky, a prominent Russian theologian and an authority on icons, indicates that the iconostasis is as follows:

\footnotetext{
“ (...) does not conceal something from the faithful [...] On the contrary, it points out for them, half blinded as they are, the mysteries of the sanctuary, opening for them, lame and crippled, the entrance to a different world locked for them by their own stagnation and crying out to their deaf ears about the Kingdom of Heaven." (Florensky 1996:40-41).
}

The iconostasis is both a boundary and a link between two worlds. It conceals the altar from the direct view of the believers, but it also unites the world that believers perceive with the divine world, through images. Icons are then considered windows on the divine reality. To suppress the iconostasis would mean to block those windows. Florensky indicates the following (1996:62-63):
"To speak figuratively, then, a temple without a material iconostasis erects a solid wall between altar and temple; the iconostasis opens windows in this wall, through whose glass we see (those of us who can see) what is permanently occurring beyond: the living witnesses to God."

While we can find icons everywhere in a Christian orthodox church, those that are recognized and revered are those placed in the iconostasis (Kenna 1985). Because the iconostasis is meant to direct the attention of the believers and reveal the reconciliation between human and divine through icons, the arrangement of the different icons in it is precisely codified in a hierarchical order. Icons are ordered by groups (chins) most frequently in three rows, with doors in the middle. The bottom row is called the worship row due to its accessibility to worshippers who can burn candles or meditate in front of those icons and directly relate to them. The icons in this tier might vary locally but this row will include an icon of Christ and one of the Theotokos on either side of the doors. The central doors are called the 'Holy doors' and are adorned with icons of the four evangelists (Matthew, Mark, Luke and John) who convey the divine message and pass the image of Christ (Luke is considered the first 
iconographer). This row might also include local saints. The second row is the deesis ("supplication" or "intercession"), dedicated to the New Testament. In the middle, there is the Christ Pantocrator (Almighty), surrounded by icons of the Theotokos, John the Baptist and the twelve Apostles or other saints. They all are in prayer and turn toward the Christ, interceding for the sinful mortals. This row is the most important because it represents the following goal of each service: turn toward God and pray. The third row is dedicated to the Twelve Great Christian Feasts. The largest churches, such as cathedrals, might include a fourth and fifth row.

What is interesting is the consistency of the iconographic program. Each icon is meaningful by itself, but it is also meaningful in its relationship with others and its position in the rows. The rows are meaningful in their relationship with each other. As Kenna (1985:362) notes "(...) the internal meaning of the icon - the significance of the holy person or scene it represents - can of course be comprehended in isolation, but it gains other meanings and further significance from its place in the scheme." The iconostasis links a specific church dedicated to a specific saint (the worship row), through the liturgy to access the saints who can intercede for sinners with the Savior (as illustrated on the deesis row). The feasts row reminds the circle of the liturgical year and of the specific occasions when God is manifested (Kenna 1985).

While there might be significant differences from one iconostasis to another, the general idea of this program must be preserved, otherwise icons may distract worshipers (Ouspensky 1992). The iconostasis has a storytelling function as it tells the story of human salvation. The worshipper does not only watch this story; he/she is invited to participate in it and make it his/hers. The relationship to visual representation is an active one (Florensky 1996). The iconographic program details potential relationships between the local church, its attendants (worshipers), and God. It also insists that those potential relationships can only be made actual by the appropriate behavior of prayers and veneration of saints who intercede for sinners and make this relationship possible. Worshippers are shown the salvation they can expect (i.e., access to God), the means through which this can be achieved (i.e., prayers, devotion) and the steps that link their local actions to this goal through the intercession of the Saints and the Theotokos. 
The relationships that the iconostasis establishes between icons are important for their meaning. Moreover, as these icons and the story they tell are used in liturgy they strengthen relationships among the community.

\section{Relationships among the community through images}

Another relational form concerning icons relates to how icons are used within the community of worshippers. To examine this, we focus on the liturgical use of icons. We refer to liturgy in a broad sense as the use of icons in a religious group according to its particular beliefs, customs and traditions.

During local feasts and festivals, icons are carried in procession counter-clockwise around the church. This attracts devotees and gathers the community. Anthropologists have noticed that migrants would return to the village to attend this ceremony (Bakalova 2001; Kenna 1985). The icon of the local Saint does not only establish a relationship with the divine, it also symbolizes a sense of belonging to a community. This double nature of the icon (as a religious image and as a community gatherer) has also been used in politics. We suggest that how the emperor engages with religious icons such not be considered only as a secular matter. While there is a divide between theology and politics, this division is less clear in the Byzantine tradition, where the Emperor is also considered a priest. As such, Byzantine Emperors often manipulated icons to their benefit (Pentcheva 2006). A first example of this is the return of Emperor John the $1^{\text {st }}$ Tzimiskes to Constantinople in 971 (Figure 4). After defeating the Russians and the Bulgarians, he had an icon placed on the triumphal chariot. Instead of mounting it, he followed the chariot on a white horse (Figure 4). Another example of such a relationship to icons is provided by Michael VIII Palaiologos, who entered Constantinople in 1261 to restore the Byzantine rule after the Latin occupation. An icon of the Virgin Hodegetria was placed on a chariot with the Emperor walking barefoot behind it, "More as an ordinary Christian than as an Emperor" as noted at the time (Bakalova 2001).

\section{FIGURE 4 AROUND HERE}

In both cases, the emperors defer to the icon to recall the origin of his legitimacy. The Emperor is the basileus, a servant and lieutenant of God, chosen by God. He is neither elected nor does he inherit this title, despite efforts by families to remain in power. It is God who 
directs the army and the Emperor must execute the divine will. The emperor indicates that he does not fight only for his own glory, but for the more meaningful glory of God.

\section{Insights for organizational research}

In this section, we extend the relational aspect of images in Christian orthodox tradition to examine organizational visual representations.

This relational dimension between images is indeed present in the visual representations used for management with the development of integrative management systems which attempt to connect different information in a systemic way. An example of such an integrative system is the development of strategy maps, one of the most popular managerial techniques (Kaplan and Norton, 2000). Strategy maps are visual representations of sets of performance measures. Each performance measure corresponds to a specific activity and provides information on this activity. However, connecting all those measures together provides a broader picture that allows the understanding of how intangible assets enhance internal processes, which, in turn, create value for customers and shareholders (Figure 5).

\section{FIGURE 5 AROUND HERE}

Similarly to iconostasis, strategy maps can be read horizontally and vertically. Each level covers a specific domain with the lower levels closer to the organization members' actions and higher levels associated with the final goal. Strategy maps are constructed around an ultimate goal, that is, of course, different from the religious goals. While visual representations in iconostasis assist believers in achieving salvation, a strategy map is meant to assist organization's members in achieving the organization's strategy. As Kaplan and Norton indicate "the best way to build strategy maps is from the top down, starting with the destination and then charting the routes that will lead there" (Kaplan and Norton 2004:52). Organizational visual representations, such as strategy maps, are meant to provide visual representations of the dominant story of the organization, i.e., its strategy. Images can contribute to the communication of, and make more accessible, the storytelling aspect of the strategy. As such, organizational visual representations operate as rhetorical machines and 
mnemonic devices which allow permanent recall of the general purpose of the strategy (Busco and Quattrone 2015; Quattrone 2015).

Those visual representations are not meant to be passively considered by organizational members; they also demand their active engagement. They insist that the articulation between the local situation of organizational members and the global performance of the organization can only be achieved through the active engagement of those members. Indeed, Kaplan and Norton see the human capital (i.e., the specific skills and talents of the organization's members) and the organizational capital (i.e., the organization's culture, leadership and the employees' ability to share knowledge) along with the organization's information systems as the foundations of a company's global performance. This relational aspect is crucial. Cheng and Humphreys (2012) suggest that it is the ability of such visual representations to show explicitly causal linkages between means and objectives which make them more appropriate to enhance both managers' information relevance and strategy appropriateness judgments more than other, less visual, tools.

Another aspect points to the political use of images, particularly by dominant actors. Existing organizational research suggests that images are commissioned and exhibited to present the point of view of the dominant (Sørensen 2010). The use of Christian orthodox icons by Emperors to present themselves as disinterested servants of higher (and less questionable) purposes suggests further that dominants can use images to de-personalize their power. Instead of presenting a strategy as serving their interests and purposes, top executives would demand managers and employees align their behaviors with the visual representations that display 'objective' causal relationships between actions and effects. Top executives might indicate that the requirements are coming from those tools rather than from themselves as a way to substitute rules-based bureaucratic legitimacy, which would come from those visual representations, to more individual-based charismatic legitimacy (Weber 1968) which they might lack and do not intend to employ. Organizational research has investigated how political processes shaped the design of visual management tools and how their implementation involved power relationships (Modell 2012), but not how those representations could be used to present as 'objective' what is actually the outcome of those political struggles and embodies the interests and goals of the dominant. More significantly, drawing from research on how Byzantine emperors used and manipulated icons to appropriate their legitimacy and associate their power to God and the Theotokos (e.g. Pentcheva 2006; Pentcheva 2010) can provide insights to examine how organizations, and their dominant 
members, use visual representations to refer to higher goals and purposes to legitimatize themselves.

\section{A THEORIZED SYNTHESIS: THE NOTION OF EPISTEMIC POWER}

Building on the insights drawn from the Christian orthodox tradition, particularly the epistemic dimension of visual representations (Elsner 2012; Mondzain 1996), we theorize the notion of epistemic power. We defined the epistemic power of a visual representation as the representation's capacity to allow the viewer to learn about an object of inquiry, which cannot be immediately understood or clearly perceived in its entirety by the viewer in a specific way. Sociologists of science refer to such objects of inquiry as epistemic objects (e.g. Ewenstein and Whyte 2009; Knorr-Cetina 2001; Rheinberger 1997). More specifically, the epistemic power of visual representations has two dimensions. It allows viewers to learn about the object of inquiry and direct their view. Furthermore, its performance will depend on how the viewer engages with the representation.

First, visual representations have epistemic power as they allow viewers to learn about an object of inquiry that is beyond their immediate perception. The object of inquiry is what the image is meant to represent. For religious icons, it is the divine, and for organizational visual representations, it might vary from planned strategy to assessments of an organizational situation. We suggest that organizational visual representations, just as religious representations, address objects of inquiry that cannot be immediately perceived and can only be approached through instantiations. In the case of religion, it concerns the essence of the divine which is beyond immediate perception. In the case of organizations, their operational complexity makes direct supervision difficult and causes them to resort to representations.

Second, the epistemic power of visual representations is not neutral, although it might appear so. Such representations allow viewers to learn about the epistemic object but also direct the attention and orient the viewer. The Christian orthodox theology indicates that icons are meant to focus and direct the attention of the believers on specific aspects. An illustrative example of that is the difference between the Hodegetria (She who shows the Way) and the Eleousa (Tenderness Virgin) icons. Organizational visual representations operate similarly, 
focusing and directing the attention of the viewer on specific aspects. This indicates the rhetorical aspects of visual representations and the potential, intentional or unintentional biases they might include when conveying knowledge about the object of inquiry. Because visual representations are not neutral, although they might appear as such to viewers, they can be used to direct action. Their apparent objectivity can also be used to gather an organization's members around them and use them to support the legitimacy and interests of those who made or commissioned them.

Further drawing from the theology of icons debates and analysis suggests that the success of the visual representations' epistemic power will very much depend on the user. First, the epistemic power of a representation will depend on how relevant users see those representations. This refers to the distinction between idolaters, iconoclasts and iconophilous, which emerged from the controversy. The iconolaters might ignore it, conflating the image with the reality; the iconophilous might use it; and the iconoclasts might reject it, stating that the inevitable biases of visual representations make them irrelevant to know about the object of inquiry. Second, the epistemic power will also depend on the visual literacy of the user. Specific knowledge is needed to understand the symbols included in visual representations and potentially the underlying assumptions. This visual literacy is necessary to understand the religious icons' symbolisms and benefit from their guidance to divine access. Similarly, managers' literacy allows them to understand organizational visual representations (such as matrices or strategic maps), which could appear cryptic to actors lacking this literacy. A consequence is that laypersons who do not have this knowledge do not experience the epistemic power of the visual representations.

\section{DISCUSSION}

In this paper, we intended to show how theology can contribute to theorizing secular organizational situations and assist in the development of new concepts. We used the Christian orthodox theology of icons to specifically further theorize the role of visual representations in secular organizations. This tradition first points to the epistemic nature of visual representations and their incomplete nature (i.e., representations provide incomplete insights on what is represented) and then points to the need, which has thus far been 
neglected, to question and theorize the relationship between the image and reality and consider how actors in organizations understand this relationship. Second, Christian orthodox theology insists on the importance of symbolism opposed to aesthetics when considering the epistemic role of visual representations. This symbolic aspect indicates the importance of actors' visual literacy. Finally, the debates and analysis of Christian orthodox theology indicate the relational aspect of images as they are both embedded within meaningful relationships with other images and used in social and power relationships. Theorizing further, we elaborate the notion of epistemic power to account for those aspects of visual representations based on the insights we drew from the Christian orthodox theology of images.

More broadly, our study provides contributions to the ongoing interest in spirituality and religion in organizational research and emerging visual management studies. In this section, we discuss these contributions in more detail and consider opportunities for future research.

\section{Theological reasoning and organizational research}

While there is an increasing interest in organizational research for spirituality and religion, this interest has mainly focused on religious organizations, the influence of religion within organizational settings, and on revealing religious aspects of secularized organizations (Sørensen, et al. 2012; Tracey 2012). Our intention is to open a new opportunity by focusing attention on the analytical potential of theology. We argue that religion and spirituality have primarily been used as ensembles of notions to draw from, while little attention had been paid to theological analysis and reasoning. We do not argue for a literal transposition of theology into organizations. Rather, we advocate a renewed attention to the intellectual legacy of theology. To illustrate how this approach might assist in generating new insights for organizational research, this paper contributes to research on visual representations in management. We use the Christian orthodox tradition of debates and analysis on icons. This eventually assisted in the development of the notion of epistemic power. In particular, we insist on the little emphasized critical potential of theology. We argue that theology is not only about storytelling but also about challenging storytelling, being critical and challenging the narrative based on rational arguments and elaborated debates that we can draw from. More broadly, we suggest that theological analysis and debates can be used to develop new insights 
and theorization regarding secular organizational settings not only by drawing from them notions and concepts but also ways of thinking and reasoning.

We also argue that theology allows us to go beyond the sociology of religion, i.e., the current dominant approach in organizational research. The sociology of religion examines religion as a phenomenon, disconnecting it from its disciplinary tenets and specific reasoning (Flanagan 2008). New insights might be gained by reconnecting religion and theology, thus taking seriously the reasoning behind religion and spirituality. Mobilizing theology would allow considering not only the notions that religious people use but also how they think since a religious person would certainly know and be influenced by the related theology. Hence, we suggest that theology is at the core of the understanding of religion as it is the related analytical reasoning. Considering religion with its own reasoning and taking seriously its reasoning without any judgmental position could allow researchers to better understand it as a social and organizational phenomenon. We argue that from an interpretative perspective, understanding peoples' religion and spirituality requires us to "see with their eyes what outsiders cannot" (Flanagan 2008).

\section{The epistemic dimension of visual representations in management}

The present research also contributes to ongoing research on organizational visual representations. Researchers are beginning to focus attention on visual representations in organizational settings. Nonetheless, this research is primarily empirically driven and focuses on methodological issues (e.g. Bell and Davison 2013; Lefsrud, et al. Forthcoming). In this context, this paper offers two important contributions to research on organizational visual representations.

The first contribution indicates the epistemic nature of visual representations. Current research primarily focuses on visual representations per se and extends the scope of research by considering visual representations in almost everything (e.g. Meyer, et al. 2013). A potential issue with such an approach is to eventually view almost everything as visual representations, just as some discourse analysis eventually concluded that almost everything is discourse (Alvesson and Kärreman 2011). The epistemic approach, drawn from Christian orthodox theology, establishes a distinction between the viewer, the visual representation and what is being represented. It insists on the importance of what is represented and that visual 
representations are never accurate renderings of what is represented. We synthetized the insights into the notion of epistemic power, which considers the capacity of visual representations to allow access to an object of inquiry. This view extends the scope of research not by considering visual representations in almost everything but by insisting on the importance of relationships between viewers and representations and between representations and what is represented. This can contribute to expanding the current research on visual representations in management but also renders it more critical by identifying the need to critically consider how representations relate to what they are meant to represent, whether this representation is more or less accurate and how it focuses and directs attention. While the present study contributes to extending the analysis of the nature of visual representations, it also indicates the need to consider the viewer, a dimension not currently considered by organizational research on visual representations. The theology of icons suggests that the relationship of viewers to images varies along two dimensions. First, this relationship depends on the level of the viewer's visual literacy. On the one hand, there are viewers that lack visual literacy and have no knowledge of the underlying symbols and codes specific to the visual representations. Those viewers can only access the aesthetic and graphical aspect of the visual representation but not its meaning. On the other hand, there are actors who have the necessary visual literacy, i.e., a deep knowledge of those symbols and codes. Those actors will access the meaning of the visual representation beyond its aesthetic aspect. They will also know about the underlying assumptions and principles and will be able to critically assess the value and relevance of the visual representation. Between those two extremes is a continuum of expertise, which depends on the actors' literacy.

Second, the relationship also depends on the attitude of the viewer. The iconoclastic controversy indicates three very different forms of engagement with views of images. The actors who see reality itself in the representation and will not try to learn further about the reality that those images represent would relate to idolaters. Those who consider and use visual representations but also more directly view the underlying reality would act as iconophilous. Finally, the actors who distrust visual representations because they cannot accurately account for reality and are potentially misleading could be identified with iconoclasts.

\section{CONCLUSION}


This article has attempted to theorize organizational visual representations rather than taking them for granted by seeking to deconstruct them. For this purpose, theology in its critical form was of particular help. There are other theological approaches in organizations (e.g. Miller 2014) that assume that theology explores and reveals secularized religious aspects within organizations (Sørensen, et al. (2012) and that draws upon concepts to examine organizational dynamics (Parker 2009). Nonetheless, thus far, theology in its analytical potential has not been used to theorize in organizations. Theology is often perceived as influencing contemporary organizational phenomenon; however, it is not considered a source of critical thinking. Indeed, recently, theology might be considered, at best, to be a source of wisdom and, at worst, to be marked by a complete lack of critical thinking.

In this article, we argue that theology is not limited to spirituality or religion and attempt to adopt a non-judgmental method (Lips-Wiersma and Mills 2014) to engage with it. More specifically, we focus on a missed aspect of theology, i.e., its critical dimension. Theology is about critical thinking; Jesuit tradition, Cordoba caliphate, and the Torah critical reading tradition are illustrative of that.

A particularly striking example of what critical theology could be is found in the Liberation Theology Movement (Gutiérrez 1971). This radical movement developed in South America as a response to the poverty and the ill-treatment of people. Beginning in the 1970s, this movement, in favor of social justice and human rights, was supporting the poor and the oppressed. Intertwining Christian theology and political activism, liberation theology attempts to re-examine the entire basic content of revelation and tradition to reveal their social and liberating dimensions. For instance, liberation theologians observed in the collegiate nature of the Trinity a model for cooperative and non-hierarchical development among humans. Moreover, their criticism of the Church was controversial as they said the Church should ally with the working class to cause social change. Rejected by The Vatican for its critical stance towards the Catholic Church's orthodoxy, this movement encouraged people to take distance on taken for granted Latin American Church organizations and institutionalization, underlining that theology could be critical and even revolutionary.

Nevertheless, we did not intent to make such a radical move. Rather, we suggest that while theology is sometimes conflated with its aspects of spirituality and religion, it is also a tremendous source of critical thinking. Theology could offer critical thinking concerning 
organizational representation as we argue in this paper but also for the wider organizational phenomenon.

Although we believe that this article provides insights regarding attention to spirituality and religion in organizational research, it also raises several intriguing possibilities for future research. We suggest that future organizational research on religion could mobilize the relevant theological framework to deepen the understanding of religious dimensions in organizational settings. 


\section{References}

Alloa, Emmanuel

2013 'Visual Studies in Byzantium: A Pictorial Turn avant la lettre'. Journal of Visual Culture 12: 3-29.

Alvesson, M. and D. Kärreman

2011 'Decolonializing discourse: Critical reflections on organizational discourse analysis'. Human Relations 64: 1121-1146.

Archbishop Puhalo, Lazar

2014 'symbolic rituals and revelation'. Clarion: Journal of Spirituality and Justice.

Armstrong, J. Scott and Roderick J. Brodie

1994 'Portfolio planning methods: Faulty approach or faulty research?'. International Journal of Research in Marketing 11: 91-93.

Augustine of Hippo

2004 City of God. Reprint edition (January 6, 2004) edn: Penguin Classics.

Bakalova, Elka

2001 'La vénération des icônes miraculeuses en Bulgarie. Aspects historiques et contemporains d'un pèlerinage'. Ethnologie française 31: 261-274.

Bell, Emma and Jane Davison

2013 'Visual Management Studies: Empirical and Theoretical Approaches'. International Journal of Management Reviews 15: 167-184.

Besançon, Alain

1994 L'image interdite: une histoire intellectuelle de l'iconoclasme. Paris: France: Fayard.

Busco, Cristiano and Paolo Quattrone

2015 'Exploring How the Balanced Scorecard Engages and Unfolds: Articulating the Visual Power of Accounting Inscriptions'. Contemporary Accounting Research 32: 12361262.

Chan-Serafin, Suzanne, Arthur P. Brief and Jennifer M. George

2013 'PERSPECTIVE - How Does Religion Matter and Why? Religion and the Organizational Sciences'. Organization Science 24: 1585-1600.

Cheng, Mandy M. and Kerry A. Humphreys

2012 'The Differential Improvement Effects of the Strategy Map and Scorecard Perspectives on Managers' Strategic Judgments'. The Accounting Review 87: 899-924.

Congregation for the Doctrine of the Faith

1990 'Donum Veritatis'.

http://www.vatican.va/roman curia/congregations/cfaith/documents/rc con cfaith doc 1 9900524 theologian-vocation en.html.

Creed, W. E. Douglas, Rich DeJordy and Jaco Lok 
2010 'Being the Change: Resolving Institutional Contradiction through Identity Work'. Academy of Management Journal 53: 1336-1364.

Damascus, John

730 'Apologia Against Those Who Decry Holy Images', http://legacy.fordham.edu/halsall/basis/johndamascus-images.asp (ed). http://legacy.fordham.edu/halsall/basis/johndamascus-images.asp, .

Day, G.

1986 Analysis for strategic market decisions. St. Paul, MN: West.

Dyck, Bruno

2014 'God on management: The world's largest religions, the "theological turn," and organization and management theory and practice' in Research in the Sociology of Organizations, Paul Tracey, Nelson Phillips and Michael Lounsbury (eds), 23 - 62: Emerald Group Publishing Limited.

Elsner, Jaś

2012 'Iconoclasm as Discourse: From Antiquity to Byzantium'. The Art Bulletin 94: 368394.

Ewenstein, B. and J. Whyte

2009 'Knowledge practices in design: The role of visual representations as 'epistemic objects". Organization Studies 30: 7-30.

Flanagan, Kieran

2008 'Sociology into Theology. The Unacceptable Leap'. Theory, Culture and Society 25: 236-261.

Florensky, Pavel

1996 Iconostasis Crestwood, New York: St. Vladimir's Seminary Press.

Gutiérrez, Gustavo

1971 Teología de la Liberación. 7th edn. Salamanca: Sigueme.

Haspeslagh, P.

1982 'Portfolio planning: Uses and limits'. Harvard Business Review 60: 58-73.

Henderson, B. D.

1970 The product portfolio. Boston: MA: The Boston Consulting Group.

Ivanovic, Filip

2012 Symbol and Icon: Dionysius the Areopagite and the Iconoclastic Crisis. OR: USA: Wipf \& Stock Publishers.

JP Morgan Management Task Force

2013 'Report of JPMorgan Chase \& Co. Management Task Force Regarding 2012 CIO Losses'.

Kaplan, Robert S. and David P. Norton 
2000 'Having trouble with your strategy? Then map it!'. Harvard Business Review 78: 167176.

2004 Strategy Maps: Converting Intangible Assets into Tangible Outcomes. Boston: HBS Press.

Kenna, Margaret E.

1985 'Icons in Theory and Practice: An Orthodox Christian Example'. History of Religions 24: $345-368$.

Khan, Farzad Rafi and Basit Bilal Koshul

2011 'Lenin in Allah's court: Iqbal's critique of Western capitalism and the opening up of the postcolonial imagination in critical management studies'. Organization 18: 303322.

King, Marissa D. and Heather A. Haveman

2008 'Antislavery in America: The Press, the Pulpit, and the Rise of Antislavery Societies'. Administrative Science Quarterly 53: 492-528.

Knorr-Cetina, K.

2001 'Postsocial relations: Theorizing sociality in a postsocial environment' in Handbook of social theory, G. Ritzer and B. Smart (eds). London: Sage.

Koerber, Charles P. and Christopher P. Neck

2006 'Religion in the Workplace: Implications for Financial Fraud and Organizational Decision Making'. Journal of Management, Spirituality \& Religion 3: 305-318.

Lefsrud, Lianne M., Heather Graves and Nelson Phillips

Forthcoming 'Analyzing visual rhetoric in organizational research' in Handbook of Innovative Qualitative Research Methods: Pathways to Cool Ideas and Interesting Papers Kimberly D. Elsbach and Roderick M. Kramer (eds).

Leloup, Jean-Yves

2000 L'Icône une école du regard. Paris: Le Pommier.

Lips-Wiersma, Marjolein and Albert J. Mills

2014 'Understanding the Basic Assumptions About Human Nature in Workplace Spirituality: Beyond the Critical Versus Positive Divide'. Journal of Management Inquiry 23: 148-161.

Martin, J. Edward

2014 A History of the Iconoclastic Controversy. Milano: Mimesis Edizioni, Mimesis international.

Meyer, Renate E., Markus A. Höllerer, Dennis Jancsary and Theo van Leeuwen 2013 'The Visual Dimension in Organizing, Organization, and Organization Research: Core Ideas, Current Developments, and Promising Avenues'. The Academy of Management Annals 7: 489-555.

Miller, Kent D. 
2014 'Organizational Research as Practical Theology'. Organizational Research Methods.

Modell, Sven

2012 'The politics of the balanced scorecard'. Journal of Accounting \& Organizational Change 8: $475-489$.

Mondzain, Marie-José

1996 Image icône économie Les sources byzantines de imaginaire contemporain. Paris, France: Seuil.

Ouspensky, Leonid

1992 Theology of the Icon. Paperback - August 1, 1992 edn: St Vladimirs Seminary Pr.

Ouspensky, Leonid and Vladimir Lossky

1999 The Meaning of Icons 2nd edition (June 15, 1999) edn: St Vladimirs Seminary Pr.

Parker, Martin

2009 'Angelic Organization: Hierarchy and the Tyranny of Heaven'. Organization Studies 30: $1281-1299$.

Pentcheva, Bissera V.

2006 'The Performative Icon'. The Art Bulletin 88: 631-655.

2010 Icons and Power: The Mother of God in Byzantium PA: USA: Penn State University Press.

Quattrone, Paolo

2015 'Governing Social Orders, Unfolding Rationality, and Jesuit Accounting Practices: A Procedural Approach to Institutional Logics'. Administrative Science Quarterly.

Rheinberger, H-J.

1997 Toward a history of epistemic things: Synthesizing proteins in the test tube. Stanford, CA: Stanford University Press.

Sørensen, Bent Meir

2010 'St Paul's Conversion: The Aesthetic Organization of Labour'. Organization Studies 31: 307-326.

Sørensen, Bent Meirer, Sverre Spoelstra, Heather Höpfl and Simon Critchley

2012 'Theology and organization'. Organization 19: 267-279.

Tracey, Paul

2012 'Religion and organization: A critical review of current trends and future directions'. The Academy of Management Annals, 6: 87-134.

Tracey, Paul, Nelson Phillips and Michael Lounsbury

2014 'Taking religion seriously in the study of organizations' in Religion and Organization Theory (Research in the Sociology of Organizations, Volume 41) Nelson Phillips Paul Tracey, Michael Lounsbury (ed), 3-21: Emerald Group Publishing Limited. 
Weber, Max

1968 Economy and Society. Guenther Roth and Claus Wittich edn. New York: NY: Bedminister Press.

Wensley, R.

1981 'Strategic marketing: Betas, boxes, or basics?'. Journal of Marketing 45: 173-181.

Whittington, Richard

2003 'The Work of Strategizing and Organizing: For a Practice Perspective'. Strategic Organization 1: 117-125. 


\section{Appendix 1: Chronology of one century of Iconoclastic struggles}

717 Accession of the Emperor Leo III who ends a period of political instability within the Empire.

754 Council of Hieria. The iconoclast attitude prevails.

726 Beginning of the Iconoclastic controversy

Leo develops the policy of removing or destroying religious images (icons). The Byzantine worship of icons has come uncomfortably close to idolatry and Leo attempts to purify and abstract Christian worship by their removal. The new policy of iconoclasm ("image breaking") meets with immediate opposition and will fiercely divide Byzantine society and politics for the next 120 years. Although primarily a religious controversy, support or rejection of iconoclasm inevitably reinforces pre-existing antagonisms or divisions in Byzantium. The army becomes a stronghold of iconoclasm while the church itself is largely iconophile (in support of icons).

780 Regency of the Empress Irene

Irene, widow of Leo III's grandson, reigns as regent for her son, Constantine VI. A

controversial figure, Irene is a determined woman whose desire to retain political control leads to the imprisonment and murder of her now-adult son in 797. Irene refers to herself as Basileos (King or Emperor).

787 Second Council of Nicaea. The first phase of iconoclasm ended in 787 when the Seventh Ecumenical Council of bishops met in Nicaea. This council affirmed the view of the iconophiles, ordering all right-believing (orthodox) Christians to respect holy icons, prohibiting at the same time their adoration as idolatry.

2802 Irene is deposed by the Logothete Nikephoros The Emperor Nikephoros I is a far-sighted political and financial planner. He places the Empire on sound financial footing.

813 Leo $\mathrm{V}$ ascends to the throne and initiates a second period of iconoclasm in 814 .

815 Council of Byzance. Iconoclast.

829 Reign of the Emperor Theophilos

to Despite on-going military conflict, the reign of Theophilos is notable for a significant level of

842 cultural contact between Byzantium and the Abbasid Caliphate.

843 The image of Christ is replaced above the Chalke Gate to the imperial palace.

In 843, Empress of Theodora proclaimed the restoration of icons and affirmed the decisions of the Seventh Ecumenical council. This event is still celebrated in the Orthodox Church as the "Feast of Orthodoxy." 
Table 1. Three attitudes toward visual representations

\begin{tabular}{lll}
\hline $\begin{array}{l}\text { Idolatrous attitude toward } \\
\text { images }\end{array}$ & $\begin{array}{l}\text { Iconoclast attitude toward } \\
\text { images }\end{array}$ & $\begin{array}{l}\text { Iconophilous attitude } \\
\text { toward images }\end{array}$ \\
\hline $\begin{array}{l}\text { Images are true and } \\
\text { trustworthy }\end{array}$ & Images are misleading & $\begin{array}{l}\text { Images are representations } \\
\text { different from the original }\end{array}$ \\
\hline There is no indescribable & $\begin{array}{l}\text { The indescribable should not } \\
\text { be described }\end{array}$ & $\begin{array}{l}\text { The indescribable can be } \\
\text { approached through images }\end{array}$ \\
\hline $\begin{array}{l}\text { Image and the depicted } \\
\text { entity are consubstantial }\end{array}$ & $\begin{array}{l}\text { Image and the depicted } \\
\text { object are consubstantial }\end{array}$ & $\begin{array}{l}\text { Image and the depicted } \\
\text { object are different in nature }\end{array}$ \\
\hline
\end{tabular}




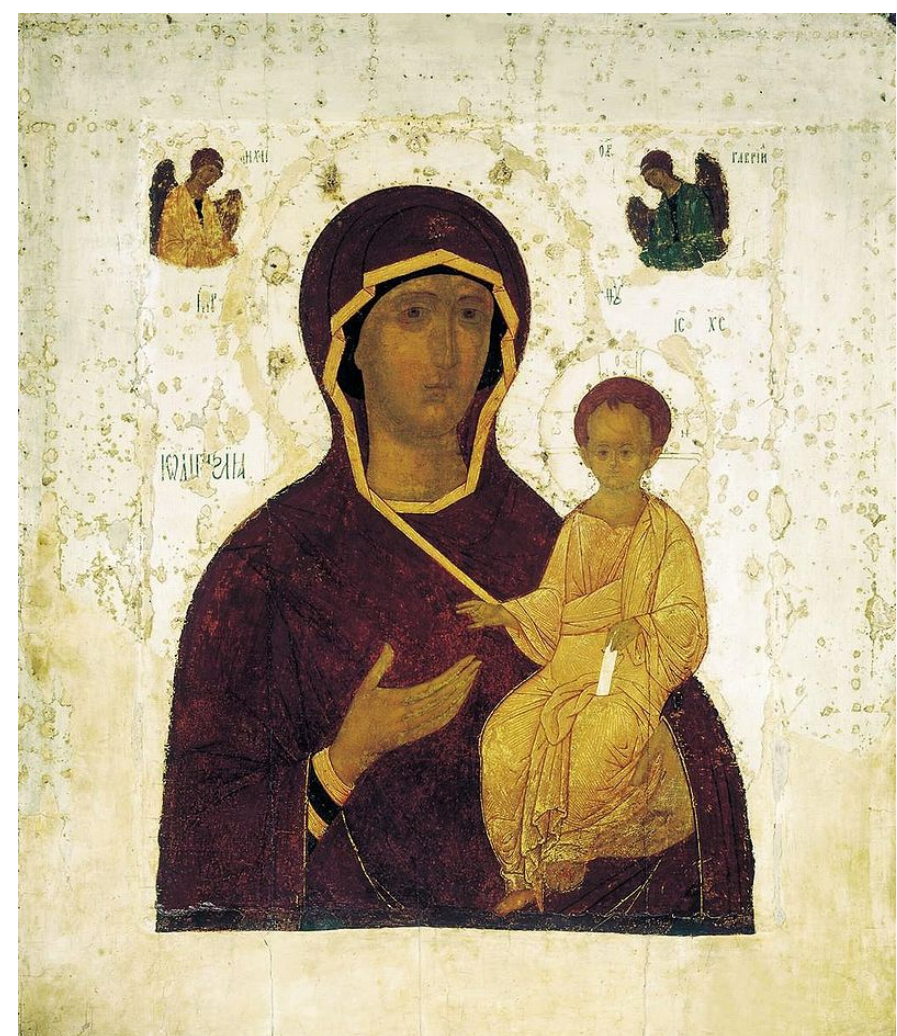

Figure 1. Virgin Hodegetria known as the Virgin of Smolensk.

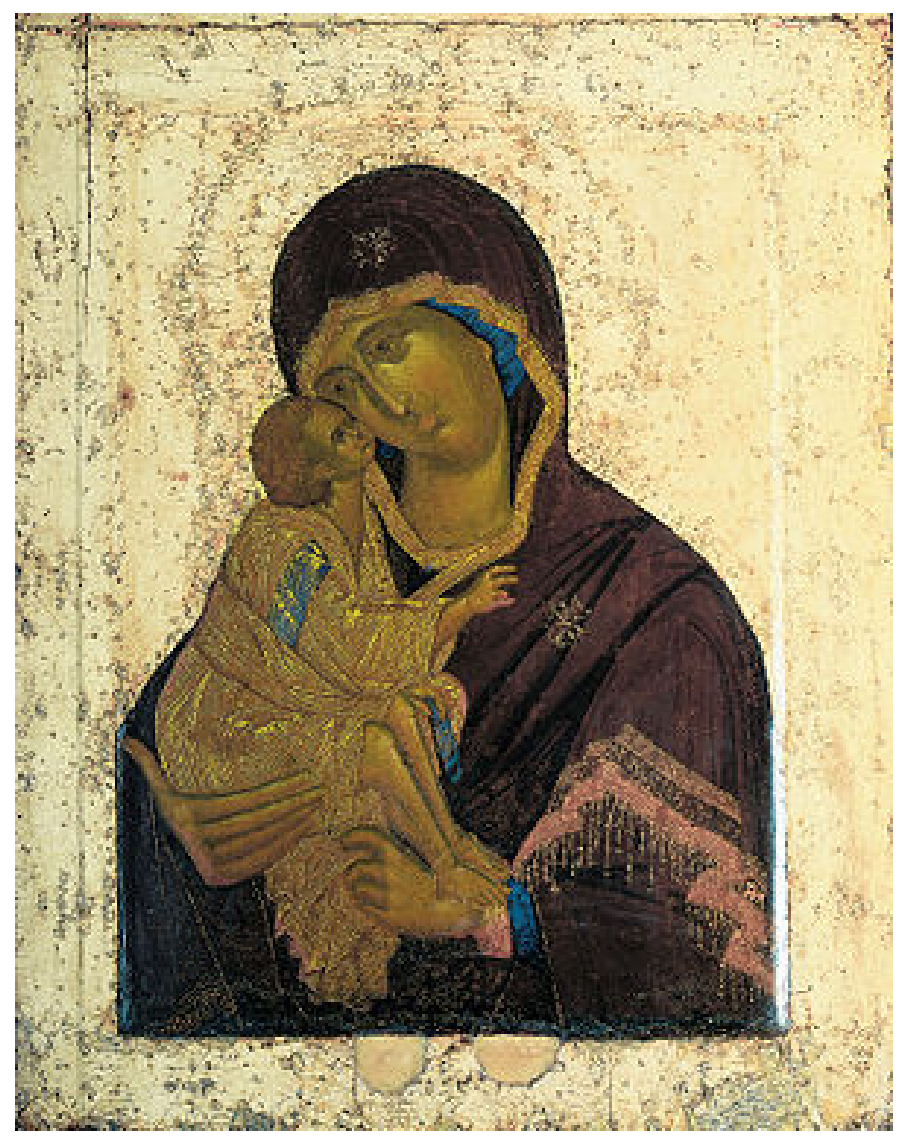

Figure 2. Virgin Eleousa known as Our Lady of the Don. $14^{\text {th }}$ Century. Tretyakov Gallery, Moscou. 


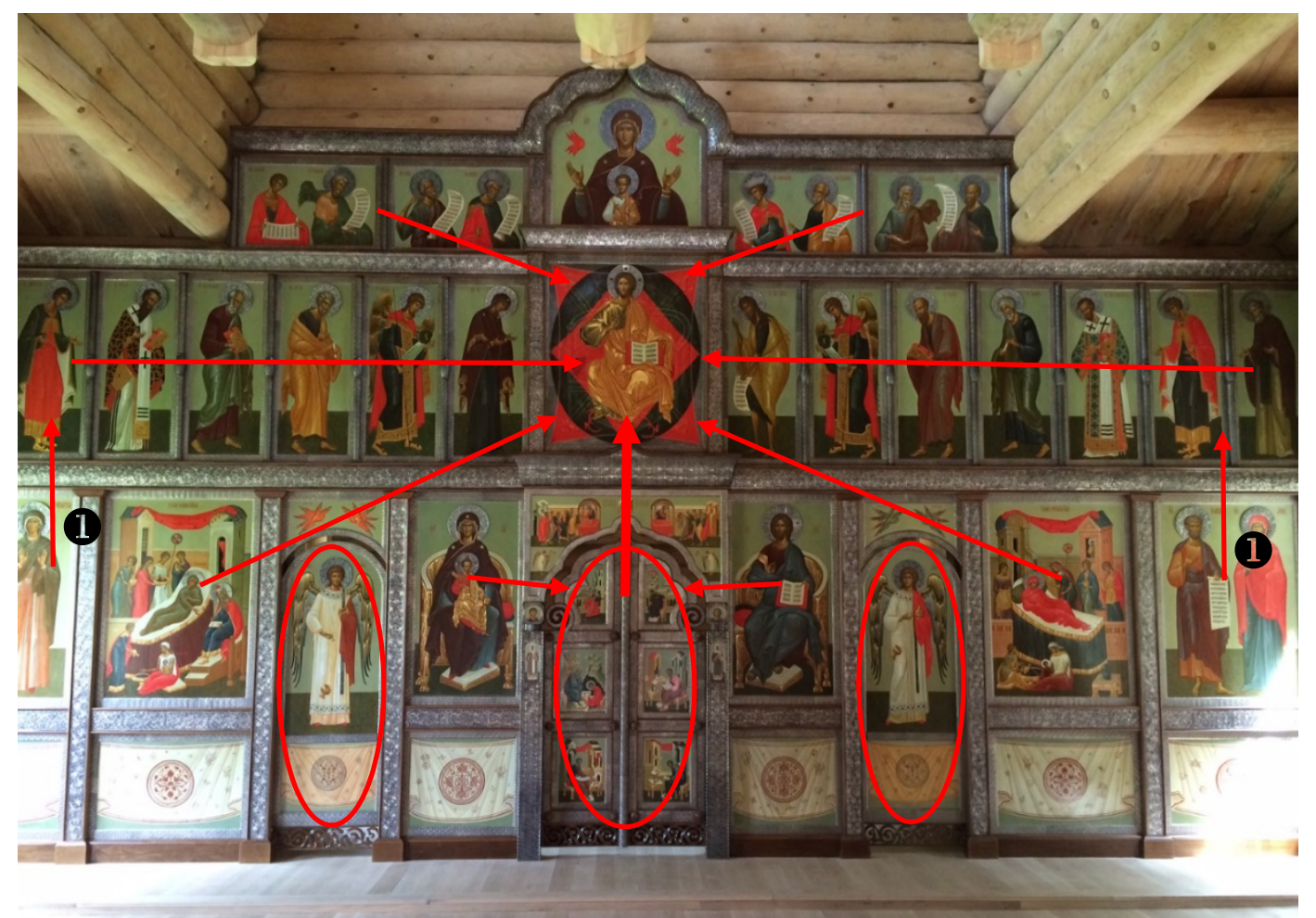

Figure 3: Iconostasis of the Christian Russian Orthodox seminar at Epinay sur Seine (France) All icons direct toward salvation through God represented by a Christ Pantocrator (Almighty) in the middle of the middle row. The bottom row (or worship row) includes icons of the Christ and the Virgin around the doors (circles), which give access to the altar. Angels and evangelists adorn those doors. They point to the divine message, which is a way to access to God (tick arrow in the middle). This row can also include more local saints to whom believers can relate more easily than to the Apostles who are in the middle row. The local saints ( ) allow a connection with those Apostles because they have not directly meet Christ but nevertheless approached Him through actions and devotions, then moving closer to the Apostles. The middle row (the deisis) includes Apostles who lived experience direct to God. They all are in prayer and turn toward the Christ, interceding for the sinful mortals. The upper row here portrays Prophets from the Old Testament who eventually forecast the coming of Christ.

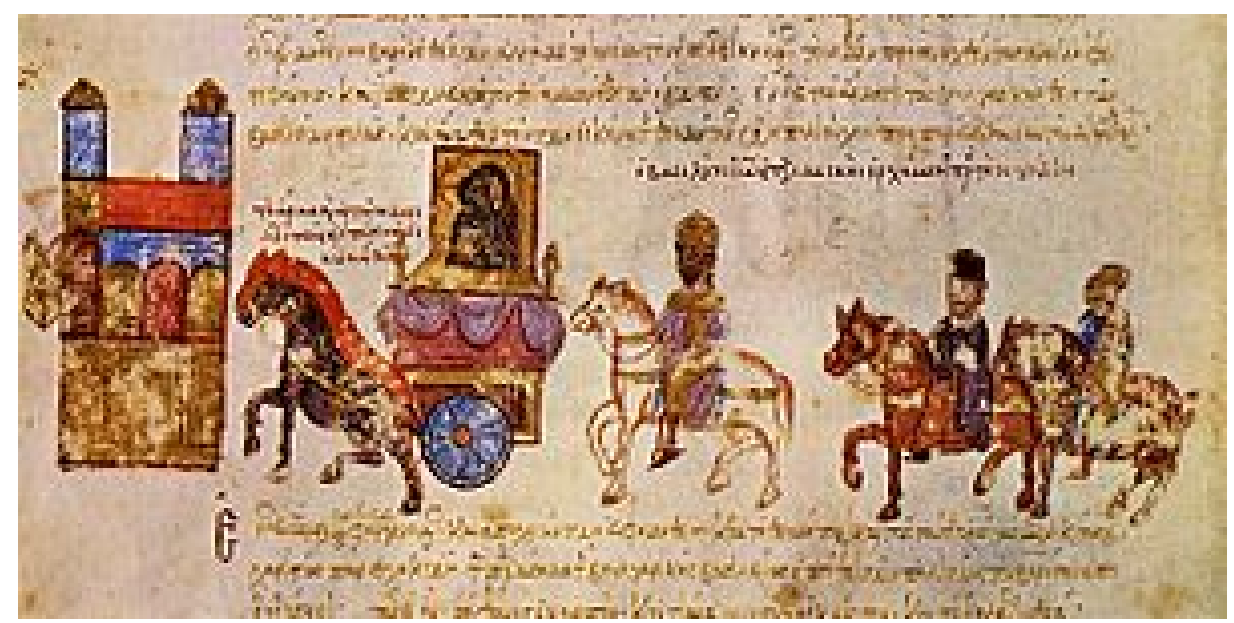

Figure 4: Emperor John 1 Tzimiskes entering Constantinople following an icon of the Virgin (Biblioteca National, Madrid) 


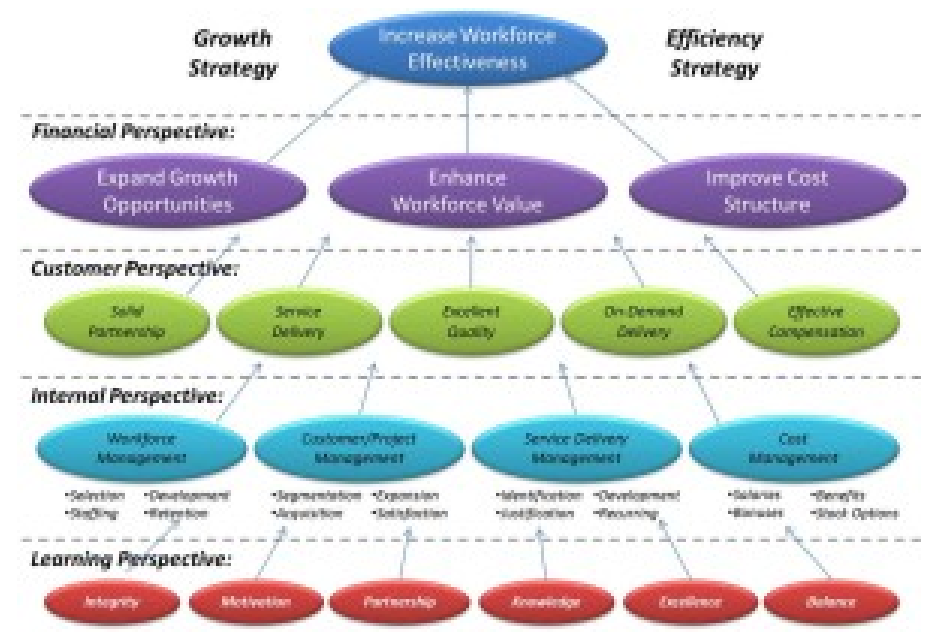

Figure 5: Strategy Maps (Kaplan and Norton 2000) 
${ }^{1}$ Such as in the Mosaic tradition which would ban representations of God as necessarily inaccurate and misleading by nature (Mondzain, 1996).

${ }^{2}$ Following the tradition of damnatio memoriae, the iconoclast texts were destroyed as heretic once the iconophilous position became official. As a consequence, we draw from compilation and secondary sources (e.g., Alloa, 2013; Baranov, 2002).

${ }^{3}$ In an appendix on page 127, the report discusses how one London-based quant was working on a new Value at Risk (VAR) model for the Chief Investment Office. In addition to not being tested correctly, the report states that the model suffered from common errors in the Microsoft Excel execution. 


\begin{tabular}{|c|c|c|c|c|}
\hline $\begin{array}{l}\text { ESSEC Business School } \\
3 \text { avenue Bernard-Hirsch } \\
\text { CS } 50105 \text { Cergy } \\
95021 \text { Cergy-Pontoise Cedex } \\
\text { France } \\
\text { Tel. + } 33 \text { (0) } 134433000 \\
\text { www.essec.edu }\end{array}$ & $\begin{array}{l}\text { ESSEC Executive Education } \\
\text { CNIT BP } 230 \\
92053 \text { Paris-La Défense } \\
\text { France } \\
\text { Tel. }+33 \text { (0) } 146924900 \\
\text { www.executive-education.essec.edu }\end{array}$ & $\begin{array}{l}\text { ESSEC Asia-Pacific } \\
5 \text { Nepal Park } \\
\text { Singapore } 139408 \\
\text { Tel. +65 } 68849780 \\
\text { www.essec.edu/asia }\end{array}$ & $\begin{array}{l}\text { ESSEC Africa-Atlantic } \\
\text { Plage des Nations } \\
\text { Sidi Bouknadel } \\
\text { Rabat-Salé } \\
\text { Morocco } \\
\text { Tel. +212 (0)5 } 30104019 \\
\text { www.essec.edu }\end{array}$ & $\begin{array}{l}\text { ESSEC Africa-Indian Ocean } \\
\text { Royal Road, Pierrefonds } \\
\text { Mauritius } \\
\text { Tel. + } 2304012400 \\
\text { www.essec.edu } \\
\text { www.icsia.mu }\end{array}$ \\
\hline
\end{tabular}

\section{- MOROCCO}

\section{Contacts}

Centre de Recherche

+33 (0)134433091

research.center@essec.fr

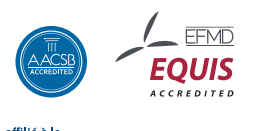

Cí CCI PARIS ILE-DE-FRANCE

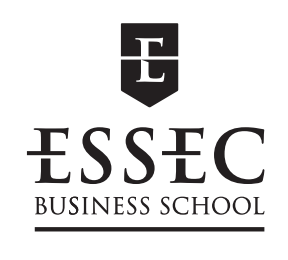

